\title{
TOTALNOŚĆ I DEKONSTRUKCJA. KILKA UWAG O SYMBOLU I ALEGORII
}

Michał Warchala

Uniwersytet Pedagogiczny w Krakowie

/// 1.

Ostatnią część książki Waltera Benjamina o niemieckim „dramacie żałobnym” otwiera ironiczna tyrada przeciw „,uzurpatorowi”, który od ponad stulecia, czyli od czasów romantyzmu (Benjamin pisze te słowa w latach 20. XX wieku) sprawuje despotyczne rządy w filozofii sztuki. To symbol, w swym romantycznym i postromantycznym wydaniu będący tak naprawdę parodia symbolu prawdziwego, czyli teologicznego. „Umizgi ówczesnych estetyków do absolutu - zauważa Benjamin - który pragnęli oni poznać świetnie, lecz bez ostatecznych zobowiązań, na dobre wprowadziły do najbanalniejszych debat wokół teorii sztuki pojęcie symbolu, poza nazwą niemające z tym prawdziwym nic wspólnego" (2013: 207). O ile w teologii symbol oznacza jedność tego, co „transcendentalne”, i tego, co materialne, o tyle romantyczna wizja sztuki osłabia napięcie, redukując paradoks do relacji między zjawiskiem i jego niewidzialna ,istotą”. Takie wykrzywienie znaczenia symbolu, nad którym ubolewa Benjamin, nie jest jest jednak tworem samego romantyzmu, lecz wynika z wcześniejszego utożsamienia sacrum z pięknem i harmonia, czego dokonał klasycyzm. Zgodnie z jego kanonami „piękne indywiduum” prawdziwej sztuki może harmonijnie reprezentować wyższy wymiar „idei”, neutralizując niejako jego obcość. $\mathrm{Na}$ granicy między klasycyzmem i romantyzmem Goethe sformułował koncepcję symbolicznej sztuki i poezji jako na tyle doskonałego przedstawienia jednostkowości, że staje się ono (niekiedy wręcz nieświadomie) reprezentacją tego, co ogólne. Przeciwieństwem i zarazem tłem dla tak rozumianego symbolu, będącego płynnym przejściem od ogólności do jednostkowości, jest alegoria: dla Goethego stanowi ona arbitralną i mechaniczną poniekąd 
egzemplifikację czy też ilustrację tego, co ogólne, za pomocą tego, co jednostkowe. „To wielka różnica, czy pisarz szuka szczegółu jako dodatku do ogółu, czy też w tym, co szczególne, przenikliwie widzi to, co ogólne. Alegoria powstaje z tamtego pierwszego usposobienia, kiedy to, co szczególne, uchodzi jedynie za przykład, exemplum tego, co ogólne; to drugie natomiast jest właściwie samą naturą poezji: wyraża ona to, co szczególne, nie myśląc o ogólnym ani na nie nie wskazując" (cyt. za Benjamin 2013: 209-210). Spór między symbolem a alegorią w poezji zostaje więc nieodwołalnie rozstrzygnięty na korzyść tego pierwszego.

Benjamin opowiada się jednak po stronie spostponowanej przez weimarskiego klasyka alegorii, nadając jej przy tym dość swoiste znaczenie. W klasycystyczno-romantycznym symbolu dostrzega drażniące pięknoduchostwo, ucieczkę w pseudo-sacrum zestetyzowanego, i dlatego fałszywego, absolutu. Symbol wedle cytowanych przez Benjamina XVIII- i XIXwiecznych teoretyków w rodzaju Georga Friedricha Creuzera cechuje „zwięzłość, jasność, wdzięk i piękno", zawiera się w nim też, co najważniejsze, „moment totalności”, w pojedynczym oglądzie ujawniający nieskończoną głębię sensu. Istnienie symbolu ujawnia „pełnię bytu”. Tyle że - odpowiada Benjamin - ta pełnia jest z konieczności skrojona na miarę człowieka i jego estetycznego osądu, a reprezentacją nieskończoności staje się ludzkie, arcyludzkie ciało greckiego boga. Jak zauważa sam Creuzer cytowany przez Benjamina: „Ów spór między nieskończonym a skończonym rozwiązuje się przeto w takim sposobie, że nieskończone, samo się ograniczając, staje się czymś ludzkim" (2013: 214). Tymczasem alegoria jako modus ekspresji, wskazuje Benjamin, zachowuje paradoksalny i antynomiczny charakter, sytuując się poza plastyczną iluzją harmonii i piękna. Jej królestwem jest barokowy dramat żałobny, który Benjamin wyciaga z odmętów krytycznoliterackiej niepamięci, przywracając jednocześnie alegorię do łask.

Jego książka nie jest jednak rozprawą z dziedziny historii czy nawet filozofii sztuki, ale metafizyczną medytacją nad kondycją świata nieodwołalnie upadłego i „podksiężycowego”, który nie może już odnaleźć drogi do Boga i w czystej immanencji musi toczyć swoje pozbawione zbawczej nadziei gry - o władzę, prestiż czy zwykłe przetrwanie. „Symulakryczne” królestwo barokowej alegorii to rzeczywistość przenicowana przez historię tak bardzo, że nie może się w niej ostać nic stałego, żaden zewnętrzny punkt odniesienia, który mógłby wiązać w całość łańcuchy alegorycznych odniesień: 
Używając decydującej kategorii czasu, którą wielka romantyczna myśl [...] wniosła w tę dziedzinę estetyki, można wnikliwie i formalnie ustalić relację symbolu i alegorii. Podczas gdy w symbolu, wraz z przebóstwieniem upadku, ulotnie objawia się poddane transfiguracji oblicze natury w świetle zbawienia, w alegorii oczom patrzącego ukazuje się facies hippocratica historii jako zakrzepły pierwotny pejzaż. Historia wraz ze wszystkim, co od początku jej towarzyszy jako to, co niewczesne, związane z cierpieniem, chybione, odciska się na obliczu - nie, w trupiej czaszce (Benjamin 2013: 217).

Ruch znaczenia jest zarazem nieskończony i „poziomy”: w barokowej historyczności i alegorii nie ma już elementu historia sacra (obecnego jeszcze w alegorii średniowiecznej), który nadawałby jej rysów eschatologicznych, a w konsekwencji dawał nadzieję na rozwiązanie i rozerwanie żelaznej klatki immanencji. Historyczność oznacza dla Benjamina rozdrobnienie, uwiąd i rozpad, ruch (paradoksalnie) zakrzepły i jałowy, którego upostaciowienie stanowi alegoryczny emblemat jako maska nadciagającej śmierci i bezradny fragment niegdysiejszej całości, której nie da się już odtworzyć.

Dlatego z perspektywy barokowego świata klasycystyczny i romantyczny symbol wydaje się cokolwiek niestosowną erupcją fałszywej eschatologii i nadziei na odnalezienie zaginionej pełni czy wertykalnego ładu znaczeń. Raz dokonanej destrukcji, sugeruje Benjamin, nie da się już jednak cofnać ani „przebóstwić”: romantyczna symbolika zbudowana na zapoznaniu czy, nieco po Freudowsku rozumianym, wyparciu alegorii, co rusz z powrotem się w nią osuwa. Charakterystyczne dla wczesnego niemieckiego romantyzmu zamiłowanie do fragmentu, w swojej hermetycznej zwartości i „niezrozumiałości” (u Schlegla czy Novalisa) przypominającego nieco barokowy emblemat, jest wedle Benjamina jednym z symptomów tego, że „rozdrobniona” alegoryczna struktura wciąż pozostaje modusem dominującym, pomimo romantycznych roszczeń do refleksyjnej totalności (por. Benjamin 2013: 250). Za podobny symptom powrotu wypartego - dodajmy, rozwijając nieco myśl Benjamina - można by uznać pewną sprzeczność (a może jedynie niejasność...) zawarta w myśleniu Goethego na temat symbolu i alegorii. Z jednej strony, cytowany wyżej ustęp wskazywałby na pewną bezpośredniość symbolu: w symbolicznym obrazie to, co ogólne, zawiera się w sposób niejako „naturalny” i niezapośredniczony - dodatkowo podkreśla to inna z maksym: „Z prawdziwym symbolizmem mamy do czynienia tam, gdzie to, co pojedyncze, reprezentuje to, co bar- 
dziej ogólne, nie jako sen [Traum] czy cień, lecz jako żywe momentalne objawienie [lebendig-augenblickliche Offenbarung] tego, co niezbadane" (cyt. za Wellek 1955: 325). Z drugiej jednak strony Goethe w innym fragmencie podkreśla dystans wytwarzany przez obraz symboliczny, kłócący się poniekąd z bliskością i niezapośredniczonym żywym charakterem zawartego w nim objawienia: symbol „zmienia zjawisko w ideę, a ideę w obraz w taki sposób, że idea zawsze jest nieskończenie aktywna i nieosiągalna w obrazie; nawet jeśli wyrazi się ją we wszystkich językach, pozostanie niewyrażalna”. (W przeciwieństwie do tego alegoria zmienia zjawisko w „pojęcie”, które zostaje „ograniczone”, ale i „w pełni zawarte i wyrażone” w obrazie alegorycznym). Sprawę gmatwa dodatkowo uwaga Goethego z jednego z bardziej znanych esejów, gdzie alegorycznemu przedstawieniu w sztuce przypisuje on cechę „bezpośredniości”, a w sztuce symbolicznej doszukuje się przedstawienia „pośredniego”, zauważając przy tym naturalnie, że po alegorycznych dziełach „można spodziewać się najmniej dobrego" (Goethe 1981: 178-179). Bezpośredniość i z a r a z e m dystans, żywa, „momentalna” pełnia i niewyrażalność wskazywałyby, że mamy tu do czynienia nie tylko z próba przechwycenia teologicznego dziedzictwa przez klasycystycznego i romantycznego uzurpatora (co pokazywał Benjamin), ale przede wszystkim, że uzurpator ów może panować tylko wtedy, gdy po cichu niejako korzysta z wpływów odsuniętego poprzednika, posługując się alegorycznym schematem, który wcześniej zdezawuował. Nigdy nie będzie więc suwerenem prawdziwym.

\section{/// 2 .}

Benjaminowskie rozpoznanie dotyczące rzeczywistych relacji między symbolem a alegorią zostało podchwycone przez późniejszych badaczy. Hans-Georg Gadamer dochodzi do podobnego wniosku, śledząc w swojej Prawdžie i metodzৃie przejście od „racjonalistycznej”, jak sam ją nazywa, estetyki oświecenia do wczesnoromantycznego myślenia o sztuce w kategoriach geniuszu i przeżycia (2004: 119 i n.). Przyznanie symbolowi prymatu nad alegorią jest jednym z kluczowych momentów tego przejścia. Filozoficzne podstawy dla jednego i drugiego tworzy wedle Gadamera Kant, odróżniając w Krytyce władzy sadzenia przedstawienie „symboliczne” od „schematycznego". To tu pojawia się nieszczęsne rozróżnienie przedstawienia „pośredniego” i „bezpośredniego”, które jak była o tym mowa wyżej, powoduje pewne zamieszanie u Goethego: o ile schematyzm, twierdzi Kant, unaocznia pojęcie bezpośrednio droga „demonstrowania”, o tyle symbol 
posługuje się pośrednią jedynie analogią. I tak symboliczne przedstawienie państwa jako maszyny nie polega na tym, że to pierwsze jest „podobne” do tej drugiej, lecz na tym, że podobieństwo zachodzi między „prawidłami refleksji nad jednym i drugim oraz nad ich przyczynowością" (Kant 1964: 300). W ten sposób symbol uruchamia pracę refleksji, której przedstawienie schematyczne nie wymaga. Cały ten ustęp Krytyki nie jest szczególnie jasny i sam Kant przyznaje, że kwestia wymaga głębszego zbadania, jednak zdaniem Gadamera został tu położony fundament pod całą romantyczną koncepcję symbolu. Refleksję Kanta będą kontynuować Schiller i Goethe. Zastosowanie pojęcia analogii ma tu, wskazuje Gadamer, sens teologiczny, który pojawi się później u Goethego: „Kant oddaje przez to sprawiedliwość prawdzie teologicznej, która ideą analogia entis nadała sobie scholastyczną postać i ludzkie pojęcia trzyma z dala od Boga" (Gadamer 2004: 123). Goethe w swej idei „momentalnego objawienia” zdaje się wprawdzie skręcać w zgoła innym kierunku, gdzie wkrótce znajdą się też romantycy: analogia entis zostanie tu zinterpretowana w nieco perwersyjny sposób jako podobieństwo między swobodnym ludzkim, „poetyckim” umysłem a Bogiem stwórca. Teologiczne zakorzenienie świadczy jednak wedle Gadamera o tym, że romantyczną waloryzację symbolu kosztem alegorii można postrzegać jako pewnego rodzaju mistyfikację, że za roszczeniami symbolu do organicznych związków z totalnością objawienia kryje się stara struktura alegoryczna. W tej sytuacji zaś, wskazuje Gadamer, odwołując się w mocno zawoalowany sposób do Benjamina, status absolutnej oczywistości przyznawany romantycznemu symbolowi w całej właściwie poromantycznej literaturze musi zostać zakwestionowany: „Czy owa działalność symboliczna nie jest w istocie i dziś ograniczona pewną przetrwałą tradycja mityczno-alegoryczna?? Jeśli zaś tak, to trzeba ponownie zrelatywizować przeciwieństwo symbolu i alegorii, które uprzedzeniom estetyki przeżycia wydawało się absolutne [...]" (2004: 131).

Ten postulat Gadamera z żelazną konsekwencja wprowadził w życie Paul de Man, u którego Benjaminowskie inspiracje w kwestii charakteru alegorii są bodaj najlepiej widoczne i owocuja, nieco podobnie jak u samego Benjamina, quasi-metafizyczną teoria podmiotu i świata przebraną w szaty teorii literatury. De Man stawia sobie za cel „rozmontowanie” romantyzmu z jego symboliczno-poetycko-teologicznymi uroszczeniami (przyjmowanymi zdaniem de Mana bezrefleksyjnie przez cała późniejsza krytykę literacka) poprzez konsekwentne zastosowanie do niego wspomnianej wyżej „decydującej kategorii czasu”. W najsławniejszym bodaj eseju de Mana, poświęconym „retoryce czasowości”, na pierwszy ogień 
idzie Samuel Taylor Coleridge, adaptujący na grunt angielski opisaną wyżej niemiecką organiczną teorię symbolu (de Man 1999: 197). Analizując drobiazgowo stosowne fragmenty wykładów, pokazuje, że nie tylko wyższość symbolu nad alegorią - która dla Coleridge’a jest czymś założonym z góry - ale i sama różnica między nimi stopniowo ulega tu zatarciu, a na plan pierwszy wysuwa się ogólne pojęcie „przeświecania” tego, co transcendentalne, ogólne i niedostępne, w tym, co czasowe i jednostkowe. Język poezji ma być właśnie miejscem owego przeświecania, przy czym konkretność i substancjalność symbolu (przeciwstawiana mechanicznej abstrakcyjności alegorii), na które nacisk kładł Goethe i od których Coleridge wychodzi, traca tu całkowicie na znaczeniu (tamże).

To jednak dopiero początek skomplikowanej argumentacji de Mana. Przyjęta przez romantyków - i, powtórzmy, bezrefleksyjnie powtarzana przez późniejszych krytyków - wizja zasadniczej wyższości symbolu nad alegoria prowadzi do rozumienia poezji jako dialektycznej relacji i więzi między podmiotem a światem: oto podmiot, odtwarzając świat w symbolicznym języku metafor, ujawnia i zarazem nadaje mu znaczenia. Poetycka symboliczna kreacja jest zatem, w myśl tej koncepcji, „,syntezą” podmiotu i przedmiotu. I tu, twierdzi de Man, pojawia się problem, jako że krytyka nie jest w stanie rozstrzygnać, co w tej relacji jest pierwsze i co ją, by tak rzec, uruchamia: natura czy poeta, przedmiot czy podmiot? Teoretycznie u Coleridge’a czy Williama Wordswortha umysł i wyobraźnia są na pierwszym miejscu: nasycają one naturę sensami do tego stopnia, że staje się ona po prostu odbiciem podmiotu, nie ma w niej nic, czego on sam by tam nie umieścił - stąd liczne oskarżenia o „egotyzm” kierowane pod adresem choćby wspomnianego Wordswortha. Z drugiej jednak strony natura ma dla poety romantycznego ogromne znaczenie: to ona prowokuje percepcje i to ona jest substratem wszelkich wyższych sensów - stąd, z kolei, przeciwstawne oskarżenia o nadmierny naturalizm i prostacką sielankowość (1999: 199-201).

Tak naprawdę, konkluduje de Man, mamy tu do czynienia ze swego rodzaju piętrową mistyfikacją, którą tworzą poeci romantyczni w rodzaju Wordswortha, Coleridge’a czy Hölderlina (i na którą dają się złapać późniejsi krytycy). Romantyczny poeta najpierw alegoryzuje naturę, odnajdując w niej synonim czegoś, co trwa mimo zmienności, by następnie uzyskane w ten sposób poczucie trwałej jedności przenieść na własne ja. W kolejnym ruchu owo trwałe ja może już z powrotem projektować symboliczne sensy na przyrodę, „uczłowieczając ją” i wytwarzając wspomnianą wyżej iluzję lustrzanego odbicia. W ten sposób symboliczność wydaje się pierwotna, 
ale tak naprawdę jest pochodna , systemu alegorycznych znaków”, który jak wskazuje de Man, zwykle ma swoje korzenie w literackiej tradycji (1999: 203, 215).

I tak docieramy do metafizycznego ostrza analiz de Mana inspirowanych myślą Benjamina: tu również mamy do czynienia z „uzurpatorem”, ale nie jest nim sam symbol, lecz podmiot, który wypierając alegorię z pola widzenia, umieszcza się w pozycji samodzielnego członu złożonej dialektyki. Podmiot pragnie przede wszystkim zatrzeć prawdę o własnej przemijalności, uwięzieniu w historycznej względności, którą ucieleśnia „system alegorycznych znaków” - „czasowość”, temporality zawartą w tytule eseju de Mana należałoby odczytywać właśnie w ten sposób, jako synonim zniszczalności i zmienności świata „podksiężycowego”, którą w barokowej alegorii odnalazł Benjamin. De Man na tej demaskacji podmiotu zbuduje zręby własnej teorii lektury i języka literackiego, nazwaną później dekonstrukcją. Podstawowa rolę będzie w niej odgrywał język interpretowany jako królestwo Benjaminowskiej alegorii: trwale „zdecentrowany” system przemieszczeń, w którym znaczenia mogą nieustannie zamieniać się miejscami, a wszelkie kategorie (wnętrze, zewnętrze, jedność, wielość itd.) pozostaja chwiejne i zależne od zmienności retorycznych figur. Przede wszystkim zaś jest to system naznaczony śmiercią, system zorganizowanego, by tak rzecz, popędu śmierci, na każdym kroku wykazujący iluzoryczność wszelkich żywych więzi. „Podmiot” i „świat” są tu na równi martwymi emblematami, a moc językowego systemu z góry unieważnia ich pretensje nie tylko do dominacji, ale nawet samodzielnego istnienia.

\section{/// 3.}

Figura popędu śmierci - użyta tu zresztą całkowicie wbrew intencjom samego de Mana, który psychoanalizę totalnie, ostentacyjnie wręcz ignoruje - prowadzi ku jeszcze innemu aspektowi Benjaminowskiej analizy Tranerspiel i alegorii. „Dramat żałobny” jest także królestwem melancholii, teologicznej acedii, będącej grzechem umysłowego lenistwa, której teorię i ikonografię barok dziedziczy z renesansu. Melencolia Dürera zapowiada już wedle Benjamina całą atmosferę baroku. Ukazuje też ścisłą więź, jaka istnieje między melancholią a alegorią: ta ostatnia jest idealnym upostaciowieniem „uśmiercenia afektów” czy „odpływu fal życiowych” charakterystycznego dla stanu chronicznej żałoby i smutku, jakim jest melancholia (Benjamin 2013: 178-179). I choć u Benjamina próżno szukać nawiązań do Freuda, to jego wywód kieruje uwagę w stronę psychologicznego pod- 
łoża procesów symbolizacji i alegoryzacji, które to zagadnienie najbardziej wnikliwie podejmują Freud i jego następcy. W tym sensie psychoanaliza dziedziczy poniekąd całą nowożytną problematykę literackiego symbolu i alegorii.

W szerokim i bardzo ogólnym sensie psychoanalityczna metoda Freuda od samego początku miała charakter „symboliczny”: histeryczne symptomy, którymi Freud zajął się zainspirowany przez Charcota, mają wszak strukturę symbolu, w której element jawny (czynności cielesne, słowa) jest znakiem ukrytych, nieświadomych sił i do nich odsyła (por. Segal 2003: 47). Podobnie rzecz ma się z marzeniami sennymi, dzięki którym Freud odkrył „królewską drogę” do nieświadomych scenariuszy pragnienia i stojących za nimi popędów: marzenie senne stanowi wedle Freuda „spełnienie pragnienia”, tyle że w zawoalowany, „symboliczny” sposób - mechanizmy takie jak kondensacja czy przesunięcie sprawiaja, że przejście od widocznego znaku (marzenie senne zachowane w pamięci przez pacjenta) do jego właściwej treści (nieświadomy scenariusz spełnienia) wymaga żmudnej rekonstrukcji, której dokonuje analityk.

Ta naturalna symboliczność psychoanalizy prowokowała liczne filozoficzne próby włączenia jej do tradycji hermeneutycznej, która w swej nowoczesnej postaci rodzi się w XVIII i XIX wieku - a więc w opisywanej przez Benjamina epoce „uzurpacji” symbolu - ale korzeniami sięga jeszcze patrystyki. Wedle sławnego wyrażenia Paula Ricœura, autora najbardziej bodaj wpływowej spośród takich filozoficznych prób, psychoanaliza mialaby być „hermeneutyką regionalna”, opisującą pewien specyficzny wycinek symbolicznego obszaru związany z ciałem, a zarazem, w szerszym sensie, „hermeneutyką podejrzeń”, kontynuującą rozpoczęte przez Marksa i Nietzschego dzieło demaskowania kulturowych i społecznych pozorów, które zasłaniają dostęp do prawdziwej natury człowieka i jego relacji z innymi. U Freuda, twierdzi Ricœur, mamy do czynienia z obydwoma elementami: negatywnym i pozytywnym, a oba opierają się na zasadach właściwych hermeneutyce symbolu. W aspekcie negatywnym Freudowska ,archeologia” nieświadomości „rozbiera” symboliczne struktury w życiu psychicznym i analizuje ich „architekturę sensu”. W napięciu między tym, co jawne, i tym, co ukryte, napięciu, które tak dobrze pokazuja zjawiska marzenia sennego i symptomu, realizuje się psychoanalityczna wersja „hermeneutyki restytucji sensu" (Ricœur 1965: 35 i nast.). Z kolei aspekt pozytywny czy też „konstruktywny” Ricœur odnajduje w zjawisku sublimacji, która oznacza przejście od prymitywnego pragnienia do wyższego sensu. Psychoanaliza nabiera charakteru dialektycznej syntezy: od archeologii odnajdującej 
właściwy, ukryty sens jawnych treści psychicznych, do teleologii sublimacji, która ocala ów sens od rozpuszczenia się w czystej energii pragnienia, a zarazem ocala samego Freuda od ześlizgnięcia się w pesymizm zakładający „zwierzęcość” człowieka i wszechwładne panowanie popędowej konieczności, otwiera jego naukę na poszukiwanie „wyższego” sensu. W ten sposób - jeśli przeniesiemy wywód Ricœura na interesujący nas tu poziom - okazuje się ona poniekąd spadkobierczynią klasycystyczno-romantycznej intronizacji symbolu z jego wertykalną, skierowaną ku górze, ku anagogicznie reprezentowanej i bliżej nieokreślonej „pełni”, strukturą.

Interpretacja Ricœura wydaje się pod wieloma względami przekonująca i inspirująca. Freud, choć marzył o uczynieniu z psychoanalizy pozytywistycznej nauki ścisłej, stworzył w końcu sztukę interpretacji na użytek talking cure, metody terapeutycznej, gdzie ewentualne „uzdrowienie” dokonuje się w symbolicznym medium słowa. Cała tak zwana „metapsychologia” Freuda, czyli teoria aparatu psychicznego, teoria popędów i ich przekształceń, ostatecznie służy uzasadnieniu i podbudowaniu tej interpretacyjnej praktyki. No i, last but not least z naszego punktu widzenia, Freud nigdy nie ukrywał swojej fascynacji Goethem oraz wywodzaccym się z romantyzmu rozumieniem natury i sztuki: bez tej fascynacji nie byłoby zapewne ani jego sztuki interpretacji, ani metapsychologii (por. Freud 2003: 30).

Problem jednak w tym, że hermeneutyczne podejście kompletnie traci z pola widzenia specyfikę owej sztuki interpretacji i Freudowskiej m e t o d y „odczytywania” nieświadomych sensów, nazbyt łatwo włączając ja w znane z filozoficznej czy nawet teologicznej hermeneutyki schematy i reguły rozumienia ${ }^{1}$. Jeśli przyjrzeć jej się bardziej wnikliwie, spojrzeniem mniej obciążonym pozornymi filozoficznymi oczywistościami, to może się okazać, że pod powłoką Freudowskiego uniwersalistycznego i postromantycznego symbolizmu kryje się coś znacznie bardziej przypominającego Benjaminowską alegorię także w jej dekonstrukcjonistycznej przeróbce zaproponowanej przez Paula de Mana.

Ricœur w swoim hermeneutycznym podejściu za punkt wyjścia obiera twierdzenie Freuda z Objaśniania marzeń sennych, że „«objaśniać marzenie senne» znaczy nadawać mu «sens», zastępować je czymś, co jako równy co do rangi, pełnowartościowy człon włącza się w łańcuch naszych akcji psychicznych" (Freud 1996: 99). Tę regułę substytucji jednego znaczenia w miejsce innego łatwo utożsamić - i tak też czyni Ricœur - z procedu-

\footnotetext{
${ }^{1}$ W dalszym wywodzie korzystam obficie z argumentacji Jeana Laplanche’a, najbardziej wnikliwego krytyka hermeneutycznego podejścia do psychoanalizy - por. zwłaszcza Laplanche 1997: 21-36 i 1999: 243-261.
} 
rą „tłumaczenia” bądź „rozumiejącego wykładania” charakterystycznego dla dyscyplin filologicznych, zwłaszcza że Freud niejednokrotnie sugeruje coś podobnego na kartach swojej książki, nazywając analityka „tłumaczem marzeń sennych”, a jawną i utajoną treść snu określając mianem „oryginału i przekładu”. A jednak ten sam rozdział, z którego pochodzi cytowany fragment, zawiera wywody, które znaczące komplikują całą sprawę. Freud wyróżnia dwie „popularne” metody objaśniania snów i przeciwstawia im własna „naukową” metodę. Pierwszy popularny sposób polega na symbolicznym zastapieniu całości treści sennej innym całościowym tekstem Freud przytacza tu biblijny przykład objaśnienia snu faraona o krowach tłustych i chudych, którego dokonuje Józef w Księdze Rodzaju. Drugi popularny sposób zostaje określony jako „metoda deszyfracyjna” i zasadza się na potraktowaniu jawnej treści sennej jako „pisma tajemnego”, którego każdy znak trzeba osobno „odcyfrować” zgodnie z przyjętym kluczem. Freud dystansuje się od obu metod: symboliczna ma "ograniczone zastosowanie” i nadaje się bardziej do egzegezy „sztucznych” snów, jakie spotykamy w literaturze, gdy chodzi zaś o metodę deszyfracyjna, ,wszystko sprowadza się do tego, że «klucz», sennik powinien być niezawodny, co do tego zaś nie ma żadnych gwarancji" (Freud 1996: 102).

Metoda, którą proponuje sam Freud, zbliża się nieco do metody deszyfracyjnej w tym sensie, że polega na rozczłonkowaniu treści sennej i analizowaniu każdego elementu osobno przy pomocy skojarzeń podawanych przez pacjenta. „Wykładnia” marzenia sennego nie przypomina więc spójnego tekstu, lecz raczej niezwykle skomplikowany schemat, w którym wokół kilku kluczowych punktów nawarstwiają się pokłady myśli i skojarzeń. Tak właśnie wygląda zapis autoanalizy słynnego „snu o zastrzyku Irmy” podany przez Freuda w omawianym tu rozdziale Objaśniania marzeń sennych: kilkanaście różnych „kręgów myśli” (troska o żonę, choroba córki, obawa przed odpowiedzialnością za pacjentów itd.) łączy się ze sobą, tworząc zawikłaną myślową strukturę.

I choć na końcu można ją sprowadzić do pojedynczego życzenia, którego spełnienie stanowi sen (w wypadku snu o Irmie chodzi o pragnienie bycia uznanym za autorytet, którego korzenie Freud odnajduje we własnym dzieciństwie), to jednak droga do wykrycia owego życzenia zawsze wiedzie przez mozolne odwracanie skutków „pracy marzenia sennego” - zabiegów kondensacji, przesunięcia czy nadmiernej determinacji, którym podlegają myśli senne. Infantylne pragnienie jest pobudką do powstania marzenia sennego, ale sens tego ostatniego realizuje się właśnie w owej pracy, którą Freud opisuje z pomoca „ekonomicznych” metafor - pragnienie jest „ka- 
pitalistą, który dostarcza kapitału „przedsiębiorcy” kierującemu „,fabryką snu”. Gdyby samo pragnienie „wyjaśniało” sens snu, objaśnianie marzeń sennych można by zredukować do typologii infantylnych życzeń. Pragnienie to jednak wyłącznie niemy impuls, którego realizacja (czy też artykulacja) nie jest możliwa poza siecią znaczeń. Tylko ta zmienna sieć „myśli sennych", Traumgedanken, mająca, jak zauważa Freud, zawsze charakter indywidualny, umożliwia dotarcie do impulsu pragnienia i zidentyfikowanie go.

Właśnie przy okazji omawiania pracy marzenia sennego Freud wprowadza kluczowe porównanie opisujące naturę marzenia sennego. Jego jawna treść przypomina rebus, fragment „pisma obrazkowego”, który oceniany jako całość na pierwszy rzut oka nie ma sensu. Dopiero podstawienie słów bądź ich fragmentów w miejsce obrazów pozwala zidentyfikować znaczenie snu: „Nagromadzone w ten sposób słowa już nie są bez sensu mogą utworzyć bardzo piękną i treściwą wypowiedź poetycką. Marzenie senne stanowi taką właśnie zagadkę obrazkową, nasi poprzednicy w dziedzinie objaśniania marzeń sennych popełnili zaś błąd polegający na tym, że uznali rebus za kompozycję rysunkowa - jako taka sprawiała wrażenie czegoś bezsensownego i bezwartościowego" (Freud 1996: 243-244). Praca marzenia sennego wytwarza zagadkę, którą rozwiązać można jedynie poprzez jej rozbicie, rozczłonkowanie i zidentyfikowanie poszczególnych elementów, które okazują się urywkami myśli sennych. Jak jednak przejść od obrazów do owych Traumgedanken? Zgodnie z przedstawionym wcześniej zastrzeżeniem Freuda nie dysponujemy żadnym kluczem umożliwiającym „deszyfrację" elementów rebusu. Jedyną wskazówką są skojarzenia osoby, której przyśnił się sen - skojarzenia rozproszone, wzajemnie wpływające na siebie, a przede wszystkim uzależnione od partykularnego kontekstu indywidualnej historii życia jednostki. Wszystkie skojarzenia sa jednakowo ważne - zgodnie z żelazną zasadą metody skojarzeniowej nie sposób któregoś odrzucić, uznawszy, że jest „nieistotne”. Jedynie umiejętność starannego segregowania skojarzeń oparta na znajomości zasad pracy marzenia sennego umożliwia zidentyfikowanie myśli sennych. Związek między nimi a elementami jawnej treści snu, ustanawiany jedynie za sprawą skojarzeń nie ma więc - wbrew temu, co twierdzi Ricœur - charakteru symbolicznego. Treść jawna „nie daje do myślenia” sama z siebie. Między nia a treścią utajona nie istnieje trwały, substancjalny związek, z jakim mamy do czynienia w przypadku relacji między symbolem $i$ tym, co symbolizowane.

Marzenie senne jest więc tworem z natury sfragmentaryzowanym i, by użyć zgrabnego wyrażenia Jacques’a Derridy, ,idiomatycznym”, którego objaśnienie polega głównie na de-konstruowaniu sztucznej całości będącej 
rezultatem gry między nieświadomym pragnieniem a wyparciem i cenzura świadomości. Jak zauważa Jean Laplanche, metoda Freudowska jest metodą „ściśle indywidualną, faworyzująca indywidualne związki zachodzące między pojedynczymi elementami i skojarzenia - kosztem wszelkiej autokonstrukcji i autoteoretyzacji [pacjenta]. To metoda analityczna w ścisłym sensie tego słowa, asocjacyjno-dysocjacyjna, rozłączająca. Można by ją nazwać «dekonstrukcyjną» - a termin Rückbildung jak najbardziej pojawia się u Freuda - gdyby nie to, że pojęcie zostało już zagarnięte i przyswojone przez zewnętrzną wobec psychoanalizy filozofię" (Laplanche 1999: 252). Inaczej zatem niż w rozmaitych wersjach hermeneutyki symbolu analizie nie towarzyszy tu nowa synteza znaczenia, które następnie można by autorytatywnie „wyłożyć”. Poszczególne znaczące elementy sennego rebusu sa nie tylko węzłowymi punktami, wokół których koncentrują się skojarzenia; są też swego rodzaju ułomkami, ruinami, fragmentarycznymi pozostałościami, których nie sposób już złożyć w całość, marzenie senne bowiem pozostaje nieodwołalnie „zdecentrowane”, tworząc system poziomych związków, rozchodzących się na wszystkie strony i niezbiegających się razem w żadnym punkcie: tego rebusu, zauważa Freud w cytowanym wyżej fragmencie, nie da się potraktować jako spójnego obrazu. W tym sensie senne rebusy i ich elementy przypominaja alegoryczne emblematy Benjamina: odłamki natury przenicowanej przez historię, upadłej pod brzemieniem czasu rozumianego jako nieustanny rozpad i zanik.

Przenicowująca historia jest tu indywidualna, niepowtarzalną w swych konfiguracjach historia podmiotu - dlatego wszelkie twory psychiczne sa tak bardzo idiosynkratyczne i żadnego uniwersalnego klucza do nich, rozumianego jako zestaw uniwersalnych reguł interpretacji, nie da się odnaleźć. Ta historia dla Freuda zaczyna się tak naprawdę w mitycznym momencie, przypominającym do złudzenia moment śmierci: to trauma, która zapada się w nieświadomość i którą naznaczone będzie całe późniejsze życie jednostki. Wszystkie fantazmatyczne scenariusze ostatecznie zmierzają do niej, do punktu, który jest zarazem miejscem narodzin pragnienia. Czy nie stanowi on zatem owego symbolicznego centrum, źródła sensu? Nie, gdyż trauma jest całkowicie niema i „pusta”, pojawia się zawsze tylko w kolejnych przebraniach, które jako jedyne pozostają dla nas dostępne i których sensu nigdy nie możemy być do końca pewni.

Tytułem dygresji można zauważyć, że Freud, nim doszedł do odkrycia całkiem paradoksalnego charakteru traumy jako zawsze nieobecnego początku, miał z nią poważny kłopot przez cały okres budowania teorii psychoanalitycznej. Początkowo, jeszcze przed napisaniem Objaśniania ma- 
rz̨eń sennych, ale już po tym, jak zaczął praktykować swą metodę talking cure, miał skłonność do nieróżnicowania skojarzeń i wspomnień - wszystkie one musiały być brane pod uwagę jako równie istotne. Ten „anarchiczny” (jak go określa Jean Laplanche) charakter metody skojarzeniowej wkrótce doprowadził do ciężkiego kryzysu. Freud biorący za dobrą monetę wspomnienia swoich pacjentów dotyczące uwiedzenia w dzieciństwie przez dorosłych doszedł jesienią 1897 roku do wniosku, że te seksualne traumy były jedynie fantazjami przedstawianymi fałszywie jako rzeczywiste fakty. Mimo tej porażki i rezygnacji z tej teorii uwiedzenia, Freud nie porzucił bynajmniej idei, że u podstaw symptomu może leżeć realne wydarzenie - przeżyta w dzieciństwie „scena pierwotna”, która nabrała znaczenia seksualnego i stała się zaczątkiem takich formacji jak symptomy, marzenia senne, czynności natrętne itd. Sceną generującą traumę może być jakiekolwiek wydarzenie, które za sprawą rodzących się popędów zostało przez podmiot obdarzone niejasnym praseksualnym znaczeniem, które - natychmiast wyparte i zepchnięte do nieświadomości - ulega wzmocnieniu i zaczyna wtórnie oddziaływać w momencie, gdy po okresie latencji indywiduum wytwarza dojrzałą, genitalną postać popędu seksualnego. Dopiero wtedy traumatyczny charakter sceny ujawnia się w pełni. Wytrwałe (by nie rzec obsesyjne) poszukiwanie owych scen widać we Freudowskich studiach przypadków: histeryczki Dory czy „człowieka od wilków”. W opisie historii tego ostatniego Freud zdecydowanie odrzuca Jungowską ideę Zurückphantasieren, zgodnie z którą traumatyczne wydarzenia z dzieciństwa miałyby być jedynie retroaktywnym wytworem dorosłych fantazji seksualnych. W nowym cyklu swoich Wyktadón ze wstepu do psychoanalizy sugeruje z kolei, że najpierwotniejszą seksualną „sceną” może być „uwiedzenie” niemowlęcia przez matkę w trakcie karmienia piersią...

Traumatyczne „sceny” zawierają zatem w sobie element realności, choć zostaje on nie do poznania przetworzony przez fantazje (generowane za sprawą popędów), oraz „spóźnionego rozpoznania” ich właściwej, seksualnej natury. Co z tego wszystkiego wynika dla terapii? Przede wszystkim to, że dla Freuda zawsze ma ona charakter „archeologiczny” - dąży do odkrycia traumatycznego jądra, które w nieskończonej ilości postaci - symptomów, marzeń sennych, czynności natrętnych, urojeń, perwersji itd. - dąży do spełnienia zawartej w nim nieświadomej, wypartej obietnicy rozkoszy. Analityk musi przebijać się przez kolejne warstwy tych zniekształceń, by móc zrekonstruować „, historię nieświadomości”, na którą składają się kolejne postaci owej najpierwotniejszej reminiscencji. Ona sama nigdy nie może się „objawić” w czystej postaci - może jedynie nakładać kolejne maski 
w postaci fantazmatycznych scenariuszy spełnienia. Scenariusze te „maja sens" nadany przez pacjenta, sens, by tak rzec, powierzchniowy. Zadaniem terapii jest rozbicie i zdarcie tej powłoki sensu, by dotrzeć do sensu pierwotnego, nieświadomego. W relacji analityk-analizowany, tak jak wyobraża ją sobie Freud, nie chodzi zatem o „otwieranie” formacji psychicznych za pomoca hermeneutycznego klucza, ale o ich likwidowanie. Jak zauważa Jean Laplanche, „metoda psychoanalityczna w swej pierwotnej postaci nie posiada żadnych kluczy, ale jedynie śrubokręty. Nie otwiera zamków, lecz je demontuje. Tylko w ten sposób, jako przestępca-włamywacz, może próbować zbliżyć się do straszliwego i komicznego zarazem skarbca nieświadomych znaczących” (Laplanche 1999: 259).

\section{$/ / / 4$.}

Alegoryczna w Benjaminowskim sensie i „dekonstrukcyjna” jeszcze na etapie pierwszego wydania Objaśniania marzeń sennych w 1900 roku Freudowska metoda interpretacji zaczęła jednak stopniowo obrastać elementami, które skierowały ją w końcu w stronę uniwersalistycznego symbolizmu - a które dziś pozwalają traktować psychoanalizę jako odłam postromantycznej hermeneutyki. Pierwszym i najważniejszym z tych elementów było pojęcie symbolu w sensie węższym, wprowadzone przez Freuda do drugiego wydania dzieła o marzeniach sennych (1909). Oznacza ono te elementy marzenia sennego, które nie poddają się odczytaniu za pomoca metody skojarzeniowej i odsyłają do uniwersalistycznie rozumianej „mitologii”, czy też, jak ujmuje to Freud, do „filogenetycznego dziedzictwa ludzkości". Symbole w tym znaczeniu to zatem typowe, uniwersalne motywy spotykane zdaniem Freuda we wszystkich kulturach i stanowiące poniekąd ich fundament (zakaz kazirodztwa, kastracja, zabójstwo pierwotnego ojca ustanawiające prawo i poczucie winy itd.). Interpretacja symboliczna jest jednak przez Freuda traktowana raczej ostrożnie, a jej obecność wynika przede wszystkim ze wspomnianych niedomagań metody skojarzeniowej. Co ciekawe, Freud zawsze - zarówno w książce o marzeniach sennych, jak i w późniejszych tekstach traktujących o metodzie psychoanalitycznej wyraźnie rozdziela metodę interpretacji symbolicznej od metody skojarzeniowej, wskazując, że pierwsza nie może w żadnym razie zastapić drugiej. W niewielkim eseju Praktykowanie objaśniania maržeń sennych w psychoanalizie (1911) interpretacja symboliczna potraktowana jest jako swoista „nadbudowa" psychoanalitycznej terapii, działanie, którego może się podjąć jedynie bardzo doświadczony analityk i to w specyficznych okolicznościach 
(por. Freud 2007: 115-119). Z kolei we Wstepie do psychoanalizy Freud jeszcze wyraźniej wskazuje, że objaśnianie symboliczne jedynie uzupełnia właściwą procedurę interpretacji snów opowiadanych przez pacjentów: „Znając zarówno utarte symbole marzeń sennych, jak i osobę śniącego, warunki, w których żyje, oraz wrażenia, po których nastąpiło marzenie senne, jesteśmy często w stanie tłumaczyć sen bez trudności, jakby od ręki. [...] Nie dajcie się jednak tym skusić. Nie jest naszym zadaniem wykonywanie sztuczek. Tłumaczenie oparte na znajomości symboliki nie może ani zastąpić, ani też mierzyć się z techniką skojarzeń. Uzupełnia ją ono tylko i dopiero w połączeniu z nią daje użyteczne rezultaty" (Freud 1957: 131). W podanym cytacie pojawia się jeszcze inna istotna cecha symboliki sennej: jej zależność od „osoby śniącego” i ,warunków, w których żyje”. Ten motyw przewija się także w Objaśnianiu marzeń sennych: nawet najbardziej typowe symbole są w jakiejś mierze uzależnione, gdy chodzi o sens, od przygodnych okoliczności związanych $z$ indywidualną historią śniącego. Jak trafnie zauważa Jonathan Lear w swoim komentarzu do Freudowskiej Traumlehre, znaczenie wszystkich marzeń sennych jest zawsze skażone ,,idiosynkratycznością”, a zatem „nieporozumieniem jest uznawanie psychoanalizy Freuda za dyscyplinę zajmująca się w pierwszym rzędzie powszechną symboliką życia psychicznego - podobną na przykład do Jungowskiej psychologii głębi” (Lear 2004: 109).

Pojęcie symbolu i symboliczności w omawianym tu sensie wprowadza jednak do Freudowskiego myślenia element „typowości”, który na tyle rozwinie się w późniejszej psychoanalizie, że ta ostatnia potocznie bywa traktowana niemal wyłącznie jako „dyscyplina zajmująca się powszechną symboliką życia psychicznego". Tendencja ta dotyczy również najbardziej kreatywnych postfreudowskich nurtów, takich jak teoria relacji z obiektem czy psychoanaliza Lacana: przy wszystkich fundamentalnych niekiedy różnicach między nimi dominuje tu uniwersalistyczna epistemologia typu i schematu. U Lacana nieświadomość staje się uniwersalną matrycą Symbolicznego, konceptualizowaną na wzór de Saussure'owskiego langue - i nawet jeśli matryca ta ufundowana jest na zasadniczym braku czy luce, wprawiającej w ruch łańcuch znaczących, to jej „systemowość” w znacznej mierze eliminuje anarchiczny czy dekonstrukcyjny charakter właściwy metodzie Freuda i związany, jak widzieliśmy, z pojęciem indywidualnej traumy. Z kolei w teorii relacji z obiektem symbolizm zostaje zredukowany do - traktowanej jako równie typowa i uniwersalna - relacji między wewnątrzpsychicznymi tworami (fantazje) a zewnętrznymi obiektami (matka, pierś matki). Jeśli, z grubsza rzecz ujmując, człony tej relacji pozostają od- 
rębne względem siebie, a zewnętrzne obiekty bądź działania są symboliczną reprezentacją nieświadomych fantazji, to możemy mówić o normalnym rozwoju: dla Melanie Klein, twórczyni całego nurtu relacji z obiektem, ten dystans i „reprezentowanie” fantazji przez obiekty stanowią podstawę budowania stabilnego ego (Klein 2007: 222 i nast.). Jeśli jednak symboliczny dystans zanika, a obiekty traktowane sa tak ,jakby były" tym samym, co fantazje, to mamy do czynienia z poważnym zaburzeniem, które Hanna Segal, najważniejsza spadkobierczyni i interpretatorka myśli Klein, nazywa „równaniem symbolicznym” (Segal 2003: 52-53). Jeszcze inaczej rzecz całą ujmuje twórca alternatywnej wobec Klein wersji teorii relacji z obiektem Donald W. Winnicott: dla niego „symbolizm” to swego rodzaju sfera pośrednia między tym, co zewnętrzne wobec jednostkowej jaźni, i tym, co wewnątrz niej, sfera kształtująca się dzięki zjawisku zabawy dziecięcej, która opiera się na logice symbolicznej reprezentacji. Tak rozumiana symboliczność jest dla Winnicotta uniwersalnym fundamentem kultury, której twory mieszczą się właśnie w owej pośredniej sferze. Symbol zawiera więc potencjalne odniesienie do totalności kulturowych sensów (por. Winnicott 2011: 27-28).

Bibliografia:

/// Benjamin W. 2013. Źródto dramatu żałobnego w Niemczech, tłum. A. Kopacki, Wydawnictwo Sic!, Warszawa.

/// Freud S. 1957. Wstęp do psychoanalizy, tłum. S. Kempnerówna, W. Zaniewicki, Książka i Wiedza, Warszawa.

/// Freud S. 1996. Objaśnianie marzeńn sennych, tłum. R. Reszke, Wydawnictwo KR, Warszawa.

/// Freud S. 2003. Selbstdarstellung/Freud présenté par lui-même, éd. bilingue, tłum. F. Cambon, Éditions du Seuil, Paris.

/// Freud S. 2007. Praktykowanie objaśniania marzeń sennych w psychoanalizie, tłum. R. Reszke, [w:] tegoż, Drieła, t. IX, Wydawnictwo KR, Warszawa.

/// Gadamer H.G. 2004. Prawda i metoda, tłum. B. Baran, Wydawnictwo Naukowe PWN, Warszawa.

/// Goethe J.W. 1981. O przedmiotach sz̨tuk plastycznych, tłum. R. Wojnakowski, [w:] tegoż, Wybórpism estetycznych, T. Namowicz red., Wydawnictwo Naukowe PWN, Warszawa. 
/// Kant I. 1964. Krytyka władzy sadzenia, tłum. J. Gałecki, Wydawnictwo Naukowe PWN, Warszawa.

/// Klein M. Znaczenie tworzenie symboli dla rozpoju ego, tłum. D. Golec, [w:] tejże, Miłość, pocそucie winy i reparacja oraz inne prace ₹ lat 1921-1945, Gdańskie Wydawnictwo Psychologiczne, Gdańsk, s. 217-230.

/// Laplanche J. 1997. Interpreter [avec] Freud, [w:] tegoż, Le primat de l'autre en psychanalyse, Flammarion, Paris, s. 21-36.

/// Laplanche J. 1999. Psychanalyse comme l'anti-hermeneutique, [w:] tegoż, Entre séduction et inspiration: l'homme, PUF, Paris, s. 243-261.

/// Lear J. 2004. Frend, Routledge, London.

/// Man P. de. 1999. Retoryka czasowości, tłum. A. Sosnowski, „Literatura na świecie", nr 10-11, s. 191-241.

/// Ricœur P. 1965. De linterpretation. Essai sur Freud, Éditions du Seuil, Paris.

/// Segal H. 2003. Marz̧enie senne, wyobraźnia i sz̨tuka, tłum. P. Dybel, Universitas, Kraków.

/// Wellek R. 1955. A History of Modern Criticism, vol. I, Yale University Press, New Haven.

/// Winnicott D.W. 2011. Zabawa a rzeczywistość, tłum. A. Czownicka, Wydawnictwo Imago, Gdańsk.

\section{/// Abstrakt}

Celem artykułu jest pokazanie kilku historycznych odsłon „sporu” między symbolem a alegoria, który po raz pierwszy pojawia się w okresie oświecenia. Wychodząc od krytyki oświeceniowego i romantycznego pojęcia symbolu dokonanej przez Waltera Benjamina w jego książce o barokowym dramacie żałobnym, pokazuję następnie, w jaki sposób zrehabilitowana przez niego przy tej okazji alegoria zaczyna odgrywać kluczowa rolę w dekonstrukcji Paula de Mana. Dla tego ostatniego staje się ona interpretacyjnym narzędziem, które podważa uświęconą przez romantyków totalność znaczenia i odsłania przewrotne gry języka z samym soba. Inny epizod tego sporu rozgrywa się w psychoanalizie Freuda, gdzie idiosynkratyczność „alegorycznego” sensu generowanego przez aparat psychiczny 
w formie marzeń sennych czy scenariuszy pragnienia wchodzi w konflikt z uniwersalnym sensem kulturowych symboli, przenikających do psychicznych wytworów.

Słowa kluczowe:

symbol, alegoria, Walter Benjamin, Paul de Man, psychoanaliza

\section{/// Abstract}

The purpose of the paper is to examine some episodes from the historical „,controversy” between symbol and allegory triggered in the period of Enlightenment. My starting point being Walter Benjamin's critique of the Enlightenment and Romantic conception of symbol in his book on German Trauerspiel I attempt to show how the notion of allegory put into new use by Benjamin becomes the key concept of Paul de Man's deconstruction. De Man makes it into an interpretative tool which undermines the totality of meaning while uncovering the subtle and games language plays with itself. The other episode of that controversy is Freud's psychoanalysis featuring the opposition between ,allegorical”, idiomatic meaning of dreams or other phantasmatic scenarios and the universal meaning of cultural symbols that find their place in psychic artefacts.

Keywords:

symbol, allegory, Walter Benjamin, Paul de Man, psychoanalysis 